\title{
The Silence of the Cell
}

\section{Blanca Bazán-Perkins*}

Departamento de Hiperreactividad Bronquial, Instituto Nacional de Enfermedades Respiratorias, México

\section{A Brief History of Cell Calcium}

Some of the most abundant metals in Earth's crust as iron, magnesium and calcium have significant roles in the regulation of cellular processes $[1,2]$. Biochemically, these metals are electrophiles capable of modifying the electron ion flow in biomolecules, by binding and orienting them [3]. One of the most versatile metals in cell physiology is the calcium ion $\left(\mathrm{Ca}^{2+}\right)$. Nowadays, many fundamental functions of the cell are $\mathrm{Ca}^{2+}$ dependent. Paradoxically, early life emerged in a scant free $\mathrm{Ca}^{2+}$ environment ( 100 nM) because the cation was maintained as insoluble salt by the high seawater $\mathrm{pH}$. In these conditions, photosynthesis was developed by autotrophs releasing molecular oxygen $\left(\mathrm{O}_{2}\right)$ from splitting water. Because $\mathrm{O}_{2}$ easily permeate through cell lipid bilayers generating many toxic effects, the incorporation of this molecule in cell metabolism through cellular respiration reduced its harmful effects, but carbon dioxide $\left(\mathrm{CO}_{2}\right)$ was produced as a waste product. The rich $\mathrm{CO}_{2}$ environment generated by cellular respiration induced a slight acidification of seawater that progressively releases $\mathrm{Ca}^{2+}$. In contrast to $\mathrm{O}_{2}$, the fatty inner core of the lipid bilayers prevented large $\mathrm{Ca}^{2+}$ influxes, but some $\mathrm{Ca}^{2+}$ permeation occurred through imperfect junctions between phospholipid domains and ionic channels $[4,5]$. In early life, $\mathrm{Mg}^{2+}$ controlled the cellular physiology, but when $\mathrm{Ca}^{2+}$ arise in the environment, many $\mathrm{Mg}^{2+}$ interacting proteins begin to be $\mathrm{Ca}^{2+}$ interacting proteins, even when cytosolic $\mathrm{Mg}^{2+}$ concentration is various orders of magnitude higher than $\mathrm{Ca}^{2+}$. These ions have similar biochemical properties, but $\mathrm{Ca}^{2+}$ can coordinate many bonds than $\mathrm{Mg}^{2+}$, and the variable hydration of $\mathrm{Ca}^{2+}$ allows to the ion to react faster than $\mathrm{Mg}^{2+}$ [2]. Then, the triggering action of $\mathrm{Ca}^{2+}$ in cell signaling is particularly valuable. Nevertheless, $\mathrm{Ca}^{2+}$ overload is potentially harmful to the cell since destabilize cytoskeleton, activate hydrolytic enzymes and cause damage in membrane lipid bilayers [2,6-8]. The key for cell survival in a $\mathrm{Ca}^{2+}$ rich environment was to establish a well-organized regulation of $\mathrm{Ca}^{2+}$ cytosolic concentrations $\left(\left[\mathrm{Ca}^{2+}\right] \mathrm{c}\right)$. In this concern, cells have developed a noteworthy complex machinery of $\mathrm{Ca}^{2+}$ binding proteins, transporters that control the membrane $\mathrm{Ca}^{2+}$ flow, and a highly specialized $\mathrm{Ca}^{2+}$ compartmentalization system. In addition, the development of a cellular code for $\mathrm{Ca}^{2+}$ signaling composed by $\mathrm{Ca}^{2+}$ transient events that take place in microdomains or globally was crucial to prevent the cell $\mathrm{Ca}^{2+}$ overload.

\section{$\mathrm{Ca}^{2+}$ binding proteins}

Key molecules in the regulation of cellular $\mathrm{Ca}^{2+}$ are the $\mathrm{Ca}^{2+}$ binding proteins. The interaction of $\mathrm{Ca}^{2+}$ with specific binding site in proteins can cause coordinate bonds with a great variability in number, angle and distances, and $\mathrm{Ca}^{2+}$ rapidly exchange its hydration degree allowing deeper protein sites binding [2,9]. Although $\mathrm{Ca}^{2+}$-binding proteins have a great structural diversity, it is commonly observed in these proteins a helix-loop-helix structural domain named EF-hand. The EF-hand displays many conformational states that operate as a multifunctional domain with different sensitivity to $\mathrm{Ca}^{2+}[10,11]$.

Other $\mathrm{Ca}^{2+}$-binding domain in proteins is $\mathrm{C}_{2}$, a concave hole in which multiple $\mathrm{Ca}^{2+}$ ions binds occur. The $\mathrm{C}_{2}$ domain proteins are involved in the binding of membrane phospholipids in a $\mathrm{Ca}^{2+}$ dependent manner and thereby act as cellular $\mathrm{Ca}^{2+}$ effectors [12]. It is common to find the EF-hand and $\mathrm{C}_{2}$ domains in the same protein [1].

\section{The extracellular and cytosolic $\mathrm{Ca}^{2+}$ environments}

The large electrochemical gradient of $\mathrm{Ca}^{2+}$ across the plasma membrane generates two different environments inside and outside the cell. The extracellular $\mathrm{Ca}^{2+}$ concentration in marine animals, as the squid, is around $10 \mathrm{mM}$, while in mammals cells are maintained in the range of 2.5 to $5 \mathrm{mM}$. Noteworthy, free basal $\left[\mathrm{Ca}^{2+}\right] \mathrm{c}$ in all cells is maintained in nanomolar range [1]. Since bacteria to vertebrates, resting $\left[\mathrm{Ca}^{2+}\right] \mathrm{c}$ are around 100 to $300 \mathrm{nM}[1,4,13]$. This resting $\left[\mathrm{Ca}^{2+}\right] \mathrm{c}$ reduces the possibility of multiple $\mathrm{Ca}^{2+}$ binds in a protein. In this sense, it is known that the bind of a single $\mathrm{Ca}^{2+}$ ion causes little or no change in the protein conformation, but multiple $\mathrm{Ca}^{2+}$ binding is essential to induce protein structural changes $[1,14]$.

Extracellular $\mathrm{Ca}^{2+}$ levels are almost stable in comparison with cytosolic. $\left[\mathrm{Ca}^{2+}\right] \mathrm{c}$ increment takes place under specific signaling and arises from two sources, the extracellular environment and the intracellular $\mathrm{Ca}^{2+}$ stores. The extracellular environment is an infinite source for $\mathrm{Ca}^{2+}$ that is accessible through various selective and non selective plasma membrane $\mathrm{Ca}^{2+}$ channels. The intracellular $\mathrm{Ca}^{2+}$ stores represent a finite source of $\mathrm{Ca}^{2+}$. The most important $\mathrm{Ca}^{2+}$ store is the endoplasmic reticulum (or sarcoplasmic reticulum in muscles), although almost all cell organelles can store $\mathrm{Ca}^{2+}[15]$. $\mathrm{Ca}^{2+}$-release from sarco-endoplasmic reticulum occurs via activation of inositol 1,4,5-trisphosphate $\left(\mathrm{IP}_{3}\right.$ ) or by $\mathrm{Ca}^{2+}$-induced-Ca ${ }^{2+}$-release (CICR) receptor-channels. $\mathrm{IP}_{3}$ is a second messenger produced in response of plasma membrane receptor activation. $\mathrm{Ca}^{2+}$ release from sarcoendoplasmic reticulum can be induced by cytosolic $\mathrm{Ca}^{2+}$ increments or cyclic ADP ribose through CICR sensitive channels [16].

Two systems remove $\mathrm{Ca}^{2+}$ from cytoplasm, the $\mathrm{Ca}^{2+}$ pumps that have high affinity, but low capacity, and the and the $\mathrm{Na}^{+} / \mathrm{Ca}^{2+}$ exchanger that has lower affinity but much larger capacity [17]. $\mathrm{Ca}^{2+}$ pumps are located in both plasma membranes (PMCA) and sarco-endoplasmic reticulum (SERCA) and are known as the "fine-tuner" of cytosolic $\mathrm{Ca}^{2+}$ concentration $[17,18]$. It has proposed that SERCA pumps are involved in signal transduction while PMCA pumps are crucial in cell survival [19].

*Corresponding author: Blanca Bazán-Perkins, Departamento de Hiperreactividad Bronquial, Instituto Nacional de Enfermedades Respiratorias, Calzada de Tlalpan 4502, Colonia Sección XVI, CP 14080, México, E-mail: perkins@servidor.unam.mx

Received November 21, 2012; Accepted November 22, 2012; Published November 26, 2012

Citation: Bazán-Perkins B (2012) The Silence of the Cell. J Bioanal Biomed 4 e109. doi:10.4172/1948-593X.1000e109

Copyright: @ 2012 Bazán-Perkins B. This is an open-access article distributed under the terms of the Creative Commons Attribution License, which permits unrestricted use, distribution, and reproduction in any medium, provided the original author and source are credited. 


\section{Cell Ca ${ }^{2+}$ regulation}

It has been proposed that the sarcoplasmic reticulum is a superficial buffer barrier that regulates $\mathrm{Ca}^{2+}$ spread between myoplasm and the extracellular environment [20]. In airways smooth muscle we observed that the buffer properties of sarcoplasmic reticulum act also in an inverse way, that is, sarcoplasmic reticulum can buffer the $\mathrm{Ca}^{2+}$ exit from the cell [21].

Cytosolic $\mathrm{Ca}^{2+}$ regulation is fundamental for cell signaling. This regulation is achieved by several mechanisms, including $\mathrm{Ca}^{2+}$ channels distribution in the plasma membrane, sarco-endoplasmic reticulum and other $\mathrm{Ca}^{2+}$ stores as mitochondria or Golgi [15]. In general, when a channel is open, a concentrated plume of $\mathrm{Ca}^{2+}$ is formed around the channel mouth and dissipates rapidly by diffusion [22]. If ryanodine $\mathrm{Ca}^{2+}$ channels are sequentially reached by the concentrated $\mathrm{Ca}^{2+}$ plume, this initially local transient can be propagated as a wave until global cellular signal occurs. These waves adopt different shapes according to their emission frequency, wavelength and velocity, and they can appear as solitary, target or spiral waves [23].

$\mathrm{Ca}^{2+}$ signaling can be regulated also by the periodicity of $\mathrm{Ca}^{2+}$ transients. Some cellular functions only needs a single or few transient $\mathrm{Ca}^{2+}$ signals, as exocytosis and contraction, but others, as cellular proliferation, requires prolonged $\mathrm{Ca}^{2+}$ signals generated by repetitive $\mathrm{Ca}^{2+}$ transients. Then, $\mathrm{Ca}^{2+}$ transients are essentially the cellular universal code of $\mathrm{Ca}^{2+}$ signalization. $\mathrm{Ca}^{2+}$ dispersion restriction can create temporal and spatial limited domains and functionally, these domains have a vital role avoiding unspecific or global $\mathrm{Ca}^{2+}$-induce signals [24]. In this context, an additional message could be added to $\mathrm{Ca}^{2+}$ code, the $\left[\mathrm{Ca}^{2+}\right] \mathrm{c}$ undershoot.

\section{$\left[\mathrm{Ca}^{2+}\right] \mathrm{c}$ undershoot}

Many excitable and non excitable cells show a fast $\left[\mathrm{Ca}^{2+}\right] \mathrm{c}$ drop below basal $\left[\mathrm{Ca}^{2+}\right] \mathrm{c}$ after the withdrawal of agonists that induced the mobilization of $\mathrm{Ca}^{2+}$ from sarco-endoplasmic reticulum [12,25-30] electrical stimulation [31,32], spontaneous $\mathrm{Ca}^{2+}$ transients [33] or during $\mathrm{Ca}^{2+}$ oscillations [34] (Figure 1). This phenomenon known as $\left[\mathrm{Ca}^{2+}\right] \mathrm{c}$ undershoot has been observed in muscles [31-37], neurons [26,27,3840], microglia [41,42], oligodendrocytes [29], spermatozoa [28,43] and chromaffin [44] and prostate stromal [45] cells. It has been widely
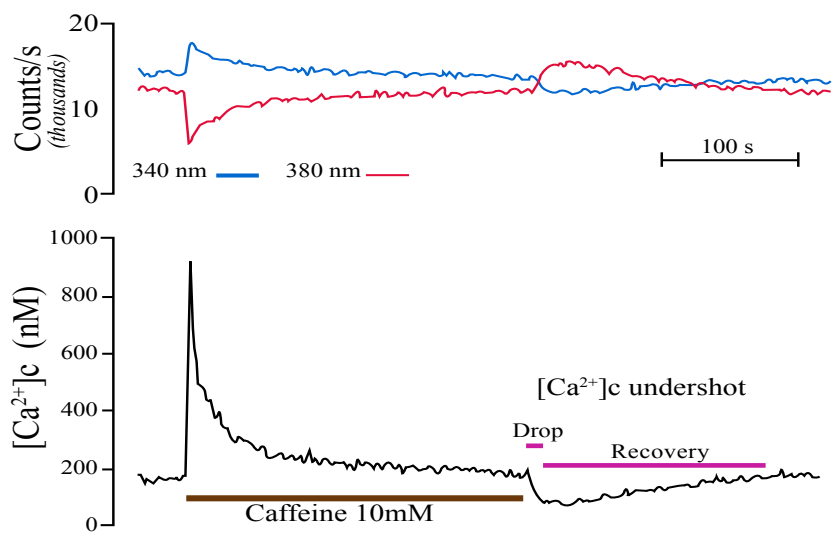

Figure 1: Typical recording of a $\left[\mathrm{Ca}^{2+}\right] \mathrm{c}$ undershoot induce by caffeine removal in an isolated smooth muscle cell from bovine trachea. Upper traces display fluorescence recordings at 340 and $380 \mathrm{~nm}$ and lower trace shows $\left[\mathrm{Ca}^{2+}\right] \mathrm{c}$. demonstrated that the $\left[\mathrm{Ca}^{2+}\right] \mathrm{c}$ drop during the undershoot is induced by the refilling of $\mathrm{Ca}^{2+}$ in sarco-endoplasmic reticulum by SERCA [2527]; while the undershoot recovery is produced by extracellular $\mathrm{Ca}^{2+}$ entry through voltage $\mathrm{Ca}^{2+}$ channels [30] or capacitative $\mathrm{Ca}^{2+}$ entry [36]. Recently, it has been observed that $\left[\mathrm{Ca}^{2+}\right] \mathrm{c}$ undershoot alterations induced by pharmacological treatments are associated to changes in sarcoplasmic reticulum $\mathrm{Ca}^{2+}$ loading mechanisms $[35,36]$.

\section{Role of $\left[\mathrm{Ca}^{2+}\right] \mathrm{c}$ undershoot in cell physiology: The silence of} the cell

Sarco-endoplasmic reticulum is a key controller of $\left[\mathrm{Ca}^{2+}\right] \mathrm{c}$ that can potentiate or attenuate cellular responses [21,27]. $\mathrm{Ca}^{2+}$ uptake by sarco-endoplasmic reticulum during undershoot has a powerful effect by reducing abruptly the $\left[\mathrm{Ca}^{2+}\right] \mathrm{c}$. The transient reduction of $\left[\mathrm{Ca}^{2+}\right] \mathrm{c}$ after $\mathrm{Ca}^{2+}$ stimulation diminished the possibility of activation of $\mathrm{Ca}^{2+}$ binding proteins, process that probably silence some signaling cascades and avoid an overload of $\mathrm{Ca}^{2+}$

Other consequence of $\mathrm{Ca}^{2+}$ undershoot is the modification of the spatiotemporal distribution of $\mathrm{Ca}^{2+}$. For example, the silences between phasic $\left[\mathrm{Ca}^{2+}\right] \mathrm{c}$ rises during caffeine-induced oscillations in neurons are attributed to $\mathrm{Ca}^{2+}$ undershoot [40]. In addition, in seizure-like events in hippocampal slice cultures, it has been proposed that the $\left[\mathrm{Ca}^{2+}\right] \mathrm{c}$ undershoot could be involved postictal depression period [39]. Then, it is possible that undershoot of $\left[\mathrm{Ca}^{2+}\right] \mathrm{c}$ is involved in the synchronization and rhythmic cell activity.

In conclusion, the deficit of intracellular $\mathrm{Ca}^{2+}$ produced by the refilling of sarco-endoplasmic reticulum during undershoot could be crucial to the triggering role of $\mathrm{Ca}^{2+}$ in cellular activity. This, $\mathrm{Ca}^{2+}$ "silences" could be a mechanism that regulates the cell excitability restricting transiently $\mathrm{Ca}^{2+}$ signaling.

\section{References}

1. Wilkins P, Wilkins RG (2003) The Role of Calcium and Comparable Cations in Animal Behaviour. Royal Society of Chemistry.

2. Williams RJ (2006) The evolution of calcium biochemistry. Biochim Biophys Acta 1763: 1139-1146.

3. Kay AB, Phipps S, Robinson DS (2004) A role for eosinophils in airway remodelling in asthma. Trends Immunol 25: 477-482.

4. 4. Montaño LM, Bazán-Perkins B (2005) Resting calcium influx in airway smooth muscle. Can J Physiol Pharmacol 83: 717-723.

5. Van Breemen D, Van Breemen C (1969) Calcium exchange diffusion in a porous phospholipid ion-exchange membrane. Nature 223: 898-900.

6. Babiychuk EB, Monastyrskaya K, Potez S, Draeger A (2009) Intracellula $\mathrm{Ca}(2+)$ operates a switch between repair and lysis of streptolysin O-perforated cells. Cell Death Differ 16: 1126-1134.

7. Plieth C (2005) Calcium: just another regulator in the machinery of life? Ann Bot 96: 1-8.

8. Trump BF, Berezesky IK (1995) Calcium-mediated cell injury and cell death FASEB J 9: 219-228.

9. Gifford JL, Walsh MP, Vogel HJ (2007) Structures and metal-ion-binding properties of the $\mathrm{Ca}^{2+}$-binding helix-loop-helix EF-hand motifs. Biochem J 405 199-221.

10. Yap KL, Ames JB, Swindells MB, Ikura M (1999) Diversity of conformational states and changes within the EF-hand protein superfamily. Proteins 37: 499507

11. Guerrero-Valero M, Marin-Vicente C, Gomez-Fernandez JC, Corbalan-Garcia $S$ (2007) The C2 domains of classical PKCs are specific Ptdlns(4,5)P2-sensing domains with different affinities for membrane binding. J Mol Biol 371: 608-621. 
12. Holland IB, Jones HE, Campbell AK, Jacq A (1999) An assessment of the role of intracellular free $\mathrm{Ca}^{2+}$ in E. coli. Biochimie 81: 901-907

13. Nalefski EA, Falke JJ (1996) The C2 domain calcium-binding motif: structural and functional diversity. Protein Sci 5: 2375-2390.

14. Laude AJ, Simpson AW (2009) Compartmentalized signalling: $\mathrm{Ca}^{2+}$ compartments, microdomains and the many facets of $\mathrm{Ca}^{2+}$ signalling. FEBS J 276: 1800-1816.

15. Berridge MJ (2012) Calcium signalling remodelling and disease. Biochem Soc Trans 40: 297-309.

16. Guerini D, Coletto L, Carafoli E (2005) Exporting calcium from cells. Cell Calcium 38: 281-289

17. Saris NE, Carafoli E (2005) A historical review of cellular calcium handling, with emphasis on mitochondria. Biochemistry (Mosc) 70: 187-194.

18. Pande J, Grover AK (2005) Plasma membrane calcium pumps in smooth muscle: from fictional molecules to novel inhibitors. Can J Physiol Pharmacol 83: $743-754$

19. van Breemen C, Chen Q, Laher I (1995) Superficial buffer barrier function of smooth muscle sarcoplasmic reticulum. Trends Pharmacol Sci 16: 98-105

20. Bazan-Perkins B, Montano LM (2002) Importancia del $\mathrm{Ca}^{2+}$ del reticulo sarcoplasmico en el músculo liso de las vías aéreas.

21. Berridge MJ (2008) Smooth muscle cell calcium activation mechanisms. J Physiol 586: 5047-5061.

22. Reas PG, Ballarò B (2004) Reaction-diffusion equations for simulation of calcium signalling in cell systems. Riv Biol 97: 443-468.

23. McCarron JG, Chalmers S, Bradley KN, MacMillan D, Muir TC (2006) $\mathrm{Ca}^{2+}$ microdomains in smooth muscle. Cell Calcium 40: 461-493.

24. Bazán-Perkins B, Sánchez-Guerrero E, Carbajal V, Barajas-LÃ ${ }^{3}$ pez C MontaÃ \pm 0 LM (2000) Sarcoplasmic reticulum $\mathrm{Ca}^{2+}$ depletion by caffeine and changes of $\left[\mathrm{Ca}^{2+}\right](\mathrm{i})$ during refilling in bovine airway smooth muscle cells. Arch Med Res 31: 558-563.

25. Collins RO, Thomas RC (2001) The effect of calcium pump inhibitors on the response of intracellular calcium to caffeine in snail neurones. Cell Calcium 30: 41-48.

26. Friel DD, Tsien RW (1992) A caffeine- and ryanodine-sensitive $\mathrm{Ca}^{2+}$ store in bullfrog sympathetic neurones modulates effects of $\mathrm{Ca}^{2+}$ entry on $\left[\mathrm{Ca}^{2+}\right] \mathrm{i}$. J Physiol 450: 217-246.

27. Harper CV, Kirkman-Brown JC, Barratt CL, Publicover SJ (2003) Encoding of progesterone stimulus intensity by intracellular $\left[\mathrm{Ca}^{2+}\right]\left(\left[\mathrm{Ca}^{2+}\right] \mathrm{i}\right)$ in human spermatozoa. Biochem J 372: 407-417.

28. Kirischuk S, Scherer J, Kettenmann H, Verkhratsky A (1995) Activation of P2purinoreceptors triggered $\mathrm{Ca}^{2+}$ release from InsP3-sensitive internal stores in mammalian oligodendrocytes. J Physiol $483: 41-57$.

29. Wu C, Sui G, Fry CH (2002) The role of the L-type $\mathrm{Ca}(2+)$ channel in refilling functional intracellular $\mathrm{Ca}(2+)$ stores in guinea-pig detrusor smooth muscle. $J$ Physiol 538: 357-369

30. Baró I, O’Neill SC, Eisner DA (1993) Changes of intracellular $\left[\mathrm{Ca}^{2+}\right]$ during refilling of sarcoplasmic reticulum in rat ventricular and vascular smooth muscle. J Physiol 465: 21-41.

31. Ganitkevich VYa, Isenberg G (1995) Efficacy of peak $\mathrm{Ca}^{2+}$ currents (ICa) as trigger of sarcoplasmic reticulum $\mathrm{Ca}^{2+}$ release in myocytes from the guinea-pig coronary artery. J Physiol $484: 287-306$

32. Mozhayeva MG, Mozhayeva GN (1996) Evidence for the existence of inosito $(1,4,5)$-trisphosphate- and ryanodine-sensitive pools in bovine endothelial cells. $\mathrm{Ca}^{2+}$ releases in cells with different basal level of intracellular $\mathrm{Ca}^{2+}$. Pflugers Arch 432: 614-622.

33. Vornanen M (1984) Activation of contractility and sarcolemmal $\mathrm{Ca}^{2+}$-ATPase by $\mathrm{Ca}^{2+}$ during postnatal development of the rat heart. Comp Biochem Physiol $\mathrm{A}$ Comp Physiol 78: 691-695.

34. Bazán-Perkins B (2012) cGMP reduces the sarcoplasmic reticulum $\mathrm{Ca}(2+)$ loading in airway smooth muscle cells: a putative mechanism in the regulation of $\mathrm{Ca}(2+)$ by cGMP. J Muscle Res Cell Motil 32: 375-382

35. Bazán-Perkins B, Sánchez-Guerrero E, Campos MG (2009) Capacitative Ca ${ }^{2}$ entry during $\mathrm{Ca}^{2+}$ undershoot in bovine airway smooth muscle. Cell Physiol Biochem 24: 161-166.

36. Wu C, Fry $\mathrm{CH}$ (1998) The effects of extracellular and intracellular $\mathrm{pH}$ on intracellular $\mathrm{Ca}^{2+}$ regulation in guinea-pig detrusor smooth muscle. J Physiol $508: 131-143$

37. Friel DD (1995) [Ca $\left.{ }^{2+}\right]$ i oscillations in sympathetic neurons: an experimental test of a theoretical model. Biophys J 68: 1752-1766.

38. Kovacs R, Schuchmann S, Gabriel S, Kardos J, Heinemann U (2001) Ca ${ }^{2}$ signalling and changes of mitochondrial function during low-Mg2+-induced epileptiform activity in organotypic hippocampal slice cultures. Eur J Neurosci 13: $1311-1319$

39. Nohmi M, Hua SY, Kuba K (1992) Basal $\mathrm{Ca}^{2+}$ and the oscillation of $\mathrm{Ca}^{2+}$ in caffeine-treated bullfrog sympathetic neurones. J Physiol 450: 513-528.

40. Beck A, Penner R, Fleig A (2008) Lipopolysaccharide-induced down-regulation of $\mathrm{Ca}^{2+}$ release-activated $\mathrm{Ca}^{2+}$ currents (I CRAC) but not $\mathrm{Ca}^{2+}$-activated TRPM4 like currents (I CAN) in cultured mouse microglial cells. J Physiol 586: 427-439.

41. Möller T, Nolte C, Burger R, Verkhratsky A, Kettenmann H (1997) Mechanisms of $\mathrm{C} 5 \mathrm{a}$ and $\mathrm{C} 3 \mathrm{a}$ complement fragment-induced $\left[\mathrm{Ca}^{2+}\right] \mathrm{i}$ signaling in mouse microglia. J Neurosci 17: 615-624.

42. Kirkman-Brown JC, Barratt CL, Publicover SJ (2003) Nifedipine reveals the existence of two discrete components of the progesterone-induced $\left[\mathrm{Ca}^{2+}\right]$ transient in human spermatozoa. Dev Biol 259: 71-82.

43. Jiménez N, Hernández-Cruz A (2001) Modifications of intracellular $\mathrm{Ca}^{2}$ signalling during nerve growth factor-induced neuronal differentiation of rat adrenal chromaffin cells. Eur J Neurosci 13: 1487-1500.

44. Wu C, Fry PM, Sui G, Fry CH (2005) Intracellular $\mathrm{Ca}^{2+}$ regulation in a human prostate stromal cell culture. Neurourol Urodyn 24: 81-88.

45. Carbajal V, Vargas MH, Flores-Soto E, Martinez-Cordero E, Bazán-Perkins B, et al. (2005) LTD4 induces hyperresponsiveness to histamine in bovine airway smooth muscle: role of SR-ATPase $\mathrm{Ca}^{2+}$ pump and tyrosine kinase. Am J Physiol Lung Cell Mol Physiol 288: L84-L92. 